Article

\title{
Production of High Added-Value Chemicals in Basfia succiniciproducens: Role of Medium Composition
}

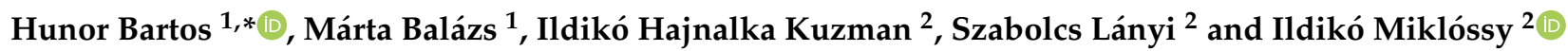 \\ 1 Faculty of Science, University of Pécs, Ifjúság 6, H-7624 Pécs, Hungary; balazsmarta@uni.sapientia.ro \\ 2 Department of Bioengineering, Sapientia Hungarian University of Transylvania, Piata Libertatii 1, \\ 530104 Miercurea Ciuc, Romania; kuzman.hajnalka@gmail.com (I.H.K.); \\ lanyiszabolcs@uni.sapientia.ro (S.L.); miklossyildiko@uni.sapientia.ro (I.M.) \\ * Correspondence: bartoshunor@uni.sapientia.ro
}

check for updates

Citation: Bartos, H.; Balázs, M.; Kuzman, I.H.; Lányi, S.; Miklóssy, I. Production of High Added-Value Chemicals in Basfia succiniciproducens: Role of Medium Composition. Sustainability 2021, 13, 3513. https:// doi.org/10.3390/su13063513

Academic Editor: Antoni Sánchez

Received: 5 February 2021

Accepted: 17 March 2021

Published: 22 March 2021

Publisher's Note: MDPI stays neutral with regard to jurisdictional claims in published maps and institutional affiliations.

Copyright: (c) 2021 by the authors. Licensee MDPI, Basel, Switzerland. This article is an open access article distributed under the terms and conditions of the Creative Commons Attribution (CC BY) license (https:// creativecommons.org/licenses/by/ $4.0 /)$.

\begin{abstract}
Succinic acid production through biological fermentation led to new pathways in the integration of renewable feedstock from different industries into biosynthesis. In this article, we investigate the population growth dynamics and succinic acid production potential of the recently isolated natural succinic acid producer, Basfia succiniciproducens, using in silico constraint-based metabolic models as well as in vitro experiments. Our work focuses on the influence of different renewable substrates and added yeast extract on fermentation dynamics, and the produced metabolites of the strain cultured in mineral (minimal) medium. According to our experiments, which were carried out as small-scale fermentations and in bioreactor conditions, glucose is the preferred carbon source, while the addition of $1 \%$ yeast extract has a significant positive effect on biomass formation. In the case of B. succiniciproducens cultured in minimal salt medium, a production potential as high as $47.09 \mathrm{mM}$ succinic acid was obtained in these conditions. Industrial applications related to this bacterial strain could contribute to new possibilities for the re-use of byproducts by using fermentation processes, leading to high added-value compounds.
\end{abstract}

Keywords: Basfia succiniciproducens; succinic acid; yeast extract effect; bacterial growth; batch cultivation

\section{Introduction}

Worldwide, bio-based succinic acid annual production adds up to 36,600 tons using strains of B. succiniciproducens [1], Escherichia coli and yeasts (possibly Candida krusei) on biomass feedstock like glycerol, sorghum or corn [2]. The projected potential market size of succinic acid is expected to reach 700.000 tons/year by 2020 [3], while biosynthesis based on renewable resources is viewed as a sustainable alternative to replace the petrochemical based succinic acid production. As Nghiem et al. reports, an LCA (Life-cycle assessment) study was conducted at Myriant's Louisiana plant. Sorghum grains were used as feedstock in comparison with petrochemical-based succinic acid production. The costs were half as much in the case of bio-based succinic acid production; USD 1.17/ $\mathrm{kg}$ compared to USD $2.89 / \mathrm{kg}$ (in the case of petrochemical-based synthesis). Furthermore, global warming potential (GWP) and non-renewable fossil cumulative energy demand (non-ren CED) in the case of petrochemical routes was 3.85 and 10.44 times higher, respectively, than the base case, where glucose was used. Based on information in the study, it is indicated that biosynthetic production should be used [4]. Use of sustainable raw materials instead of petrochemicals is of great importance, in order to reduce the negative health, social and economic impact of air pollution, as well as to contribute to the development of circular economy [5-15]. Ferone et al. reports that high-sugar-content beverages (HSCBs) can be used for succinic acid production [16]. Whey or bakery waste also can be used as Louasté et al. and Zhang et al. present $[17,18]$. Glucose can be derived from many renewable sources, including the linear glucose chain which builds cellulose as Ramesh et al. explain [19]. As Kuenz et al. report, after several steps (hot water extraction, concentration, 
ultrafiltration, recovery of monomeric/oligomeric carbohydrates) xylose can be derived from birch wood [20]. The transesterification of waste frying oil results in a step by step method to achieve glycerol [21].

In recent years, bio-based chemical precursor production have become a strongly growing industry, especially for biopolymer and bioplastic compounds [22-24]. Various bacterial strains, such as E. coli and Mannheimia succiniciproducens (further shown in Table 1) are used for the production of different platform molecules [23-30].

Several biotechnology companies (BioAmber, Succinity, Myriant, Reverdia) produce thousands of tons of succinic acid with microorganisms such as E. coli, M. succiniciproducens and other microbial strains mentioned in Table 1 [31], mainly from renewable carbon sources. Succinic acid or amber acid is a naturally occurring compound in various forms of esters [4], due to its wide range of applications in the pharmaceutical, chemical and food industry. It is included in the list of the top 12 platform chemicals by the US Department of Energy.

For the successful bio-based production of a target molecule, several criteria have to be reached, mainly cheap substrates and fermentative conditions on one hand, and high titers, production rates, and yield on the other. In order to address these issues, different microorganisms in different conditions have been tested over the last decade to optimize the production potential. Some of the potential industrial hosts are presented in "Table 1".

Table 1. Potential microbial candidate strains for succinic acid production through fermentation.

\begin{tabular}{cccc}
\hline Bacterial Strain & Reached Titer $\left(\mathbf{g} \cdot \mathbf{L}^{-\mathbf{1}}\right)$ & Substrate & Reference \\
\hline $\begin{array}{c}\text { Anaerobiospirillum } \\
\text { succiniciproducens }\end{array}$ & 100 & Sorbitol, glycerol & {$[32]$} \\
\hline $\begin{array}{c}\text { Actinobacillus } \\
\text { succinogenes }\end{array}$ & 50 & Corn stover & {$[33]$} \\
\hline A. succinogenes & 109 & Glucose & {$[4]$} \\
\hline $\begin{array}{c}\text { Corynebacterium } \\
\text { glutamicum }\end{array}$ & 113 & Glucose & {$[34]$} \\
\hline $\begin{array}{c}\text { B. succiniciproducens } \\
\text { B. succiniciproducens }\end{array}$ & 17 & $\begin{array}{c}\text { Arundo donax } \\
\text { hydrolysate }\end{array}$ & {$[3]$} \\
\hline B. succiniciproducens & 5.21 & Crude glycerol & {$[35]$} \\
\hline
\end{tabular}

Cimini et al. [22] reports that Arundo donax was used as feedstock for biosynthesis of succinic acid after preliminary hydrolysis of the raw material. Spent yeast cells as a nitrogen source and corn fiber as a carbon source were used by the research group of Chen [37]. In these conditions, a succinic acid yield of $67.7 \%$ from $70.3 \mathrm{~g} \cdot \mathrm{L}^{-1}$ total sugars was reached with an A. succinogenes strain. Later on, Liu et al. used pretreated sugarcane bagasse as substrate to obtain $18.88 \mathrm{~g} \cdot \mathrm{L}^{-1}$ succinic acid with E. coli BA204 strain under anaerobic fermentation [38]. These raw materials are theoretically sustainable and cost advantageous. Their limitation, however, consists in the presence of different inhibitors due to pretreatment such as furfural, acetate or 5-hydroxymethylfurfural (HMF), which can have a remarkable impact on cell growth $[3,39]$.

B. succiniciproducens is a member of the Pasteurellaceae family, which was first isolated from bovine rumen juice in 2008 and described in detail by the German chemical company BASF in Ludwigshafen, Germany [40]. The presented microorganism is a prominent succinic acid producer due to its facultative anaerobic metabolism and broad substrate utilization spectrum [41].

Currently, metabolic reconstructions are widely used to simulate and analyze the metabolic potential of an organism under different environmental and genetic conditions $[42,43]$. Here, we utilize a systems biology approach to determine the metabolic flux 
distribution and growth rate of B. succiniciproducens, using flux balance analysis (FBA) mathematical modeling to quantitatively predict microbial metabolism under steady-state conditions.

The goal of this work was to monitor the population growth dynamics and metabolic profile of the B. succiniciproducens bacterial strain under different conditions, namely different carbon sources and concentration of yeast extract. Several substrate concentrations were tested and their effect on the fermentation was assessed. Bioreactor experiments were conducted after several preliminary smaller scale tests in mineral media.

\section{Materials and Methods}

\subsection{In Silico Simulations}

In our simulations, we used the most recent metabolic reconstruction of B. succiniciproducens, representing the base model, which accounts for more than 60 reactions and metabolites [44]. Simulations were carried out using MATLAB (Mathworks Inc., Natick, MA, USA) and COBRA Toolbox software packages with Gurobi Optimizer (Gurobi Inc., Ann Arbor, MI, USA) [45,46]. During simulations, the substrate uptake rates were fixed as follows: glucose, xylose, glycerol to $7.7 / 9.24 / 15.06 \mathrm{mM} \mathrm{gDW}^{-1} \mathrm{~h}^{-1}$, respectively, based on literature data [44]. For maintaining the carbon number in the case of each substrate (glucose - 6 carbon atoms, xylose -5 carbon atoms, glycerol-3 carbon atoms), well calculated fluxes were used. Two types of flux analyses were performed; firstly, substrate and oxygen uptake rate were fixed, as described above. In the second case, theoretical maximum predictions were simulated, which meant that fixing the quantity of biomass could be produced (this value was set to $0.1 \mathrm{~h}^{-1}$ ) near the above-mentioned constraints. Regarding the environmental conditions, the oxygen uptake rate was set to zero to create anaerobic conditions. Simulations were carried out by solving a linear optimization problem (FBA, (1)) with a biologically relevant objective function, namely biomass formation:

$$
\begin{gathered}
\max \mathrm{Z}=\mathrm{c}^{\mathrm{T}} \mathrm{v} \\
\text { subject to } \mathrm{Sv}=0 \\
\mathrm{v}_{\mathrm{lb}}<\mathrm{v}<\mathrm{v}_{\mathrm{ub}}
\end{gathered}
$$

where $\mathrm{Z}$ is the objective function for maximization or minimization, $\mathrm{c}$ is a vector of weights, presenting how each reaction marked with $\mathrm{v}$ contributes to the objective function, $\mathrm{S}$ is the stoichiometric matrix, and $\mathrm{v}_{\mathrm{lb}}$ and $\mathrm{v}_{\mathrm{ub}}$ mean the lower and upper bounds/limits of the fluxes. For example, the objective function can be the maximum production of biomass or a given product (organic acid) [43].

\subsection{Strain}

The examined strain B. succiniciproducens (DSM-22022) was obtained from DSMZGerman Collection of Microorganisms and Cell Cultures [1]. Cells were rehydrated in TSB (Tryptic soy broth) media, containing $17 \mathrm{~g} \cdot \mathrm{L}^{-1}$, peptone from soymeal $3 \mathrm{~g} \cdot \mathrm{L}^{-1}$, $\mathrm{D}(+)$-glucose $2.5 \mathrm{~g} \cdot \mathrm{L}^{-1}, \mathrm{NaCl} 5 \mathrm{~g} \cdot \mathrm{L}^{-1}, \mathrm{~K}_{2} \mathrm{HPO}_{4} 2.5 \mathrm{~g} \cdot \mathrm{L}^{-1}$, $\mathrm{pH}$ was set to 7 (chemicals were purchased from VWR and Sigma-Aldrich, Taufkirchen, Germany). General culture maintenance was carried out at $37^{\circ} \mathrm{C}$ and $130 \mathrm{rpm}$ in a shaking incubator (Sartorius CERTOMAT ${ }^{\circledR}$ BS-T, Yumpu, Switzerland) for $8 \mathrm{~h}$.

\subsection{Microplate Experiments}

Small volume population growth dynamics studies were carried out in a 96-well microplate (BRAND plates ${ }^{\circledR}$, Taufkirchen, Germany) and set-up and absorbance was monitored on $\lambda=595 \mathrm{~nm}$ by a FLUOStar Optima (BMG Labtech GmbH, Ortenberg, Germany) microplate reader. $100 \mu \mathrm{L}$ total volume of media per well on microplate set-up were inoculated with the same cell density (initial $\mathrm{OD}_{595}$ of 0.3 ) and population growth dynamics parameters were followed by an in situ measurement of optical density at $595 \mathrm{~nm}$, without changing the total volume. Applied culture conditions were as follows: incubation at $\mathrm{pH}=6.8$ incubation temperature $37^{\circ} \mathrm{C}$, optical density at $595 \mathrm{~nm}, 40$ cycles of $1800 \mathrm{~s}$ cycle time, $90 \mathrm{~s}$ shaking with $150 \mathrm{rpm}$ before each measurement. Population growth dynamics 
were examined on the tested three substrates: glucose, xylose and glycerol in 5-15-30-50 and $70 \mathrm{~g} \cdot \mathrm{L}^{-1}$ concentration. Throughout the fermentations, minimal media was used with the following composition: $0.1 / 1 \mathrm{~g} \cdot \mathrm{L}^{-1}$ yeast extract, $1 \mathrm{~g} \cdot \mathrm{L}^{-1} \mathrm{NaCl}, 0.2 \mathrm{~g} \cdot \mathrm{L}^{-1} \mathrm{MgCl}_{2} \cdot 6 \mathrm{H}_{2} \mathrm{O}$, $0.2 \mathrm{~g} \cdot \mathrm{L}^{-1} \mathrm{CaCl}_{2} \cdot 2 \mathrm{H}_{2} \mathrm{O}, 3 \mathrm{~g} \cdot \mathrm{L}^{-1} \mathrm{~K}_{2} \mathrm{HPO}_{4}, 5 \mathrm{~g} \cdot \mathrm{L}^{-1}\left(\mathrm{NH}_{4}\right)_{2} \mathrm{SO}_{4}$ (chemicals from $\mathrm{VWR}$ and Sigma-Aldrich, USA).

\subsection{Bioreactor Fermentation and Metabolic Profile Analysis}

Conditions in the bioreactor in all experiments were $37^{\circ} \mathrm{C}, 50 \mathrm{~cm}^{3} \cdot \mathrm{min}^{-1} \mathrm{CO}_{2}$ flow rate, $\mathrm{pH}=7$, and agitation speed was controlled at $150 \mathrm{rpm}$ (radial impeller), using the above-described minimal medium with $50 \mathrm{~g} \mathrm{~L}^{-1}$ substrate. During the fermentation carried out in the bioreactor, the $\mathrm{pH}$ was monitored by continuous measurements and was regulated with $1 \mathrm{M} \mathrm{NaOH}$ and $1 \mathrm{M} \mathrm{HCl}$. In this work for fermentations, a performant Sartorius Biostat ${ }^{\circledR}$ (Taufkirchen, Germany) A Plus system with BioPAT ${ }^{\circledR}$ (Goettingen, Germany) MFCS/DA monitoring and controlling unit was used with $1 \mathrm{~L}$ total volume reactor vessel and $0.5 \mathrm{~L}$ working volume. During fermentation, the samples $(2 \mathrm{~mL})$ were taken every two hours for monitoring key parameters and the produced organic acids (succinic acid, acetic acid, formic acid, lactic acid) quantity through the fermentation time. The preparation of samples for high pressure liquid chromatography analysis was the following: culture samples were centrifuged for $10 \mathrm{~min}$ at $14,000 \mathrm{rpm}$ and filtered over $0.45 \mu \mathrm{m}$ Whatman ${ }^{\circledR}$ (Taufkirchen, Germany) sterile filters. Analysis of organic acids and carbohydrates was carried out using the Agilent Infinity 1260 HPLC system, equipped with diode array detection (DAD) and refractive index detector (RID), respectively. In autosampling mode, $20 \mu \mathrm{L}$ samples of the filtered culture supernatants were analyzed, separated on a Coregel $87 \mathrm{H} 3$ column. Measurements were carried out using the following parameters: $50{ }^{\circ} \mathrm{C}$ column temperature, mobile phase was $0.008 \mathrm{~N} \mathrm{H}_{2} \mathrm{SO}_{4}$ with $600 \mathrm{~mL} \cdot \mathrm{min}^{-1}$ flowrate.

\section{Results and Discussion}

By using sustainable feedstocks, as well as minimal mediums (containing ideally inorganic salts), the production of value-added components (e.g., succinic acid) redounds to a cost-efficient solution. While this article shows the usability of different substrates, the literature reports that the origins of these can be explained. In order to contribute to the understanding of target metabolite production, we proposed the investigation of population growth dynamics and target product forming potential in different substrate conditions of the recently isolated natural succinic acid producer B. succiniciproducens, using in silico constraint-based metabolic models and in vitro experiments.

Constraint-based simulations were carried out for the strain under the specified conditions-glucose uptake rate set to the closest to that observed experimentally, anaerobic conditions-and the results show that, on glucose, the optimal growth rate for this strain is $0.3 \mathrm{~h}^{-1}$. Throughout predictive simulations along the target reaction (biomass), there are several metabolites which are produced such as succinic acid, acetic acid, lactic acid and formic acid, the concentrations of which are determined in $\mathrm{mM} \mathrm{gDW}^{-1} \mathrm{~h}^{-1}$. Using flux balance analysis and theoretical maximum predictions, we can see the succinic acid production differences between undetermined and fixed biomass (undetermined vs. fixed). In the case of each substrate, the predictions show a doubled succinic acid flux. Glucose and xylose reach 5.57 and $5.79 \mathrm{mM} \mathrm{gDW}^{-1} \mathrm{~h}^{-1}$ fluxes, respectively, compared with glycerol, which presents a lower flux with a $4.52 \mathrm{mM} \mathrm{gDW}^{-1} \mathrm{~h}^{-1}$ value in normal conditions (undetermined biomass flux). By setting the constraint on biomass to 0.1 value, we can see an increased succinic acid flux in each case. If pathways to biomass creation are limited, carbon fluxes are headed to organic acids that can be produced. Results are presented in Figure 1. 


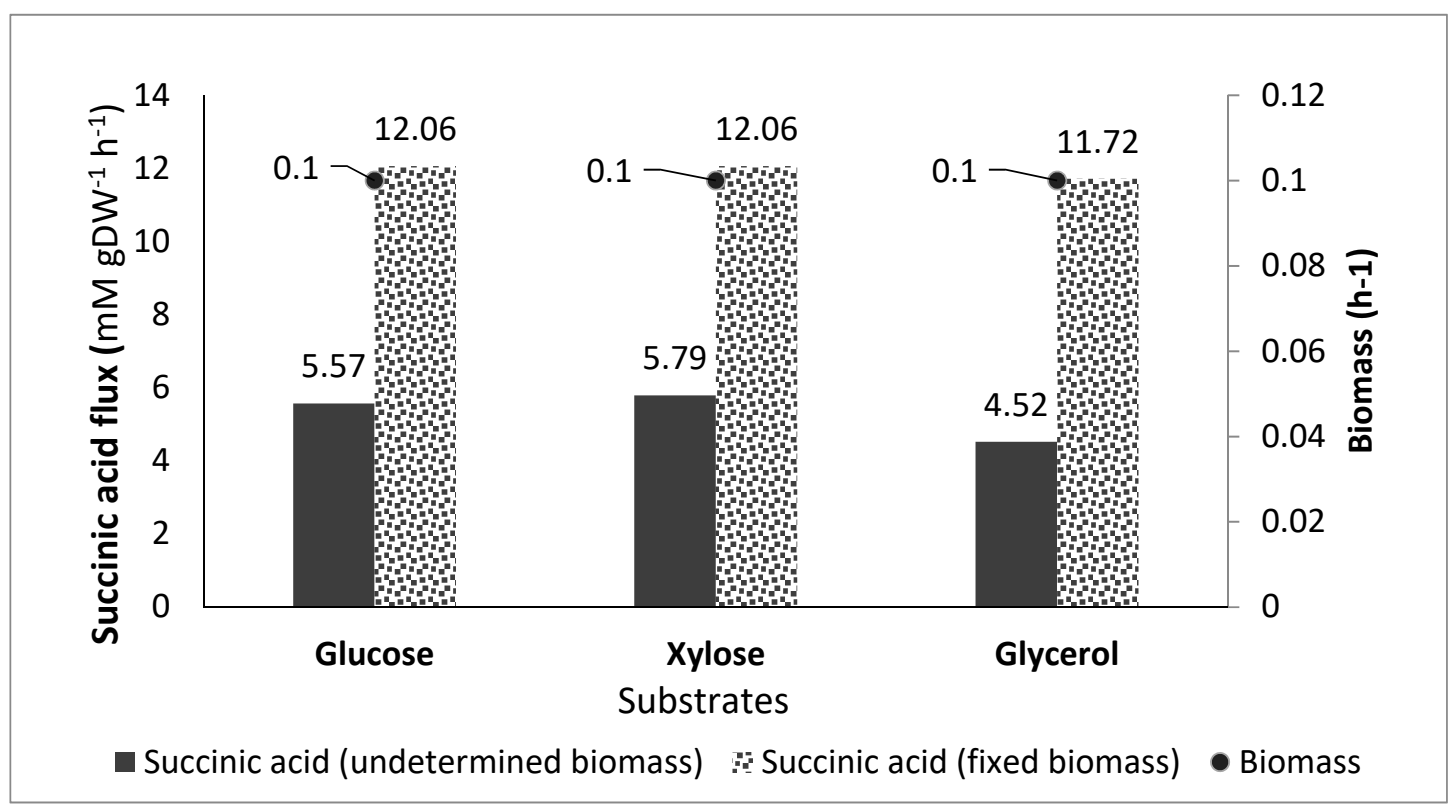

Figure 1. Succinic acid fluxes using flux balance analysis and theoretical maximum predictions (in silico experiments).

Thus, our goal in this phase was to assess, in small-scale cultures, the effect of different renewable substrates (glucose, xylose and glycerol) on population growth dynamics of the strain in mineral media, as well as to what extent the essential vitamin and amino acid containing yeast extract would contribute to biomass formation. Cultivation condition in this set up can be considered microaerobic due to the volume of the cultures (100 $\mu \mathrm{L}$ culture/well) and reduced shaking during fermentation. A first set of experiments was carried out using minimal medium with different substrate $\left(5-70 \mathrm{~g} \cdot \mathrm{L}^{-1}\right)$ and yeast extract concentrations ( 0.1 and $1 \mathrm{~g} \cdot \mathrm{L}^{-1}$ ). Utilization of minimal media was based on the theory that metabolic modelling is based on mathematic exchange reactions. These reactions are described in minimal conditions, where media composition has the least impact on cell activity. The impact of yeast extract and substrate concentration on cellular growth under the specified environmental conditions was assessed using a microplate reader, evaluating, in real time, the potential substrate inhibition on cell growth. Results describing microplate experiments are shown in "Figure 2", where we can observe that B. succiniciproducens is able to grow even on high substrate concentrations $\left(70 \mathrm{~g} \cdot \mathrm{L}^{-1}\right)$. The highest optical density in microtiter plate experiments was found in the case of xylose, reaching a maximum OD of 1.33 , for an initial substrate concentration of $30 \mathrm{~g} \cdot \mathrm{L}^{-1}$ supplemented with $1 \mathrm{~g} \cdot \mathrm{L}^{-1}$ yeast extract. Regarding the differences between carbon sources, xylose can be considered the most effective substrate from the tested range, as cultures grown on this substrate presented the highest OD values under every condition tested. Moreover, in the case of this substrate, our culture presented the shortest adaptation period/phase under this experimental setting. Considering our results from microplate experiments, it seems that, in B. succiniciproducens, the initial substrate concentration did not significantly influence the population growth dynamics, but rather was controlled by the concentration of yeast extract. In the case of glycerol, in every condition tested, we observed a reduced growth potential of the strain on this hardly assimilable substrate compared to other examined substrates (glucose, xylose). In the case of this substrate, the growth-promoting effect of yeast extract is obvious; our cultures showed a maximal $\mathrm{OD}_{595}$ value of around 1.2, regardless of the concentration of substrate, in the case of the addition of $1 \mathrm{~g} \cdot \mathrm{L}^{-1}$ yeast extract. The critical inhibitory concentration for glycerol was also evaluated in microtiter plates and found to be $50 \mathrm{~g} \cdot \mathrm{L}^{-1}$ in our experimental setting. 

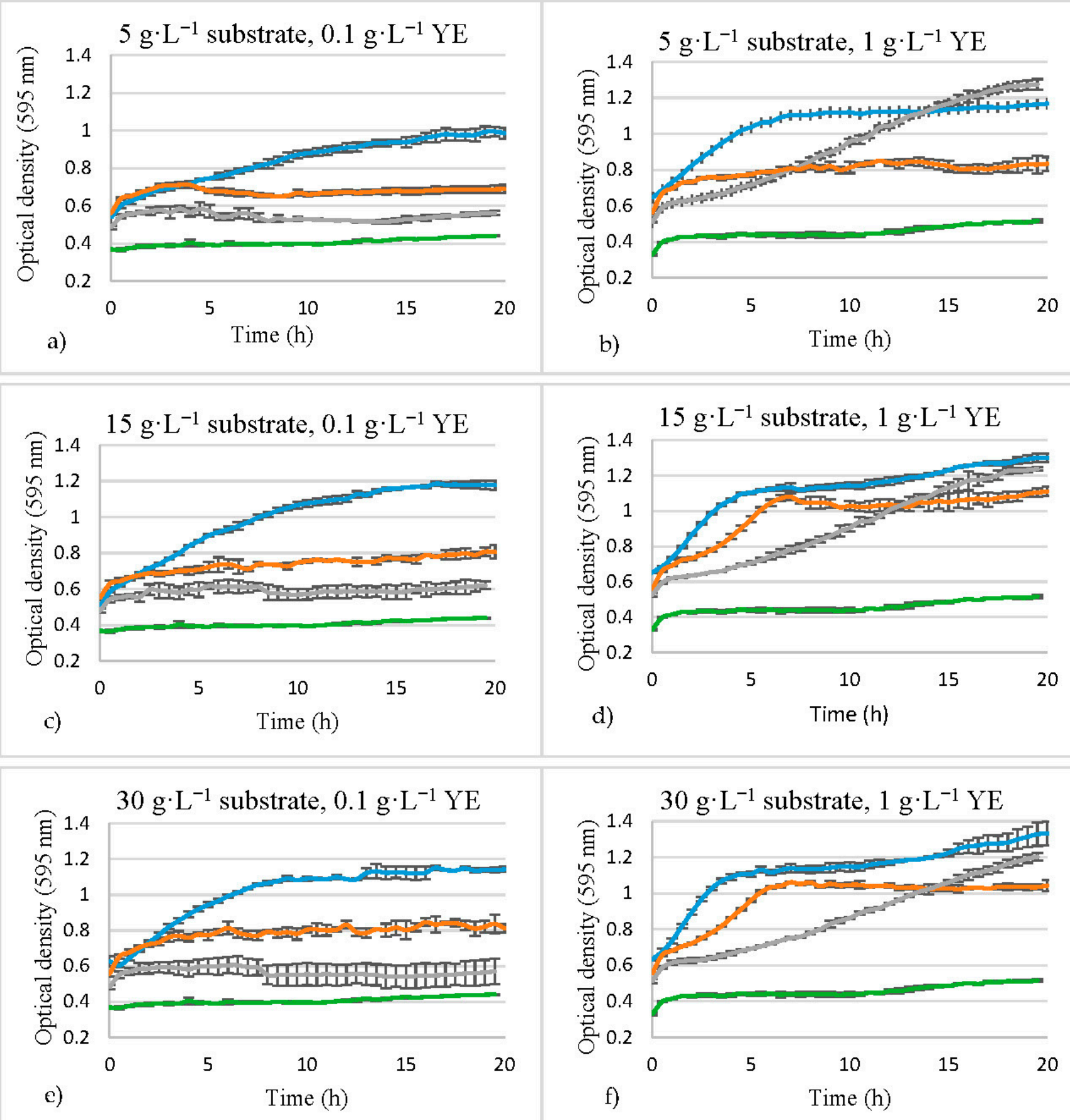

Figure 2. Cont. 


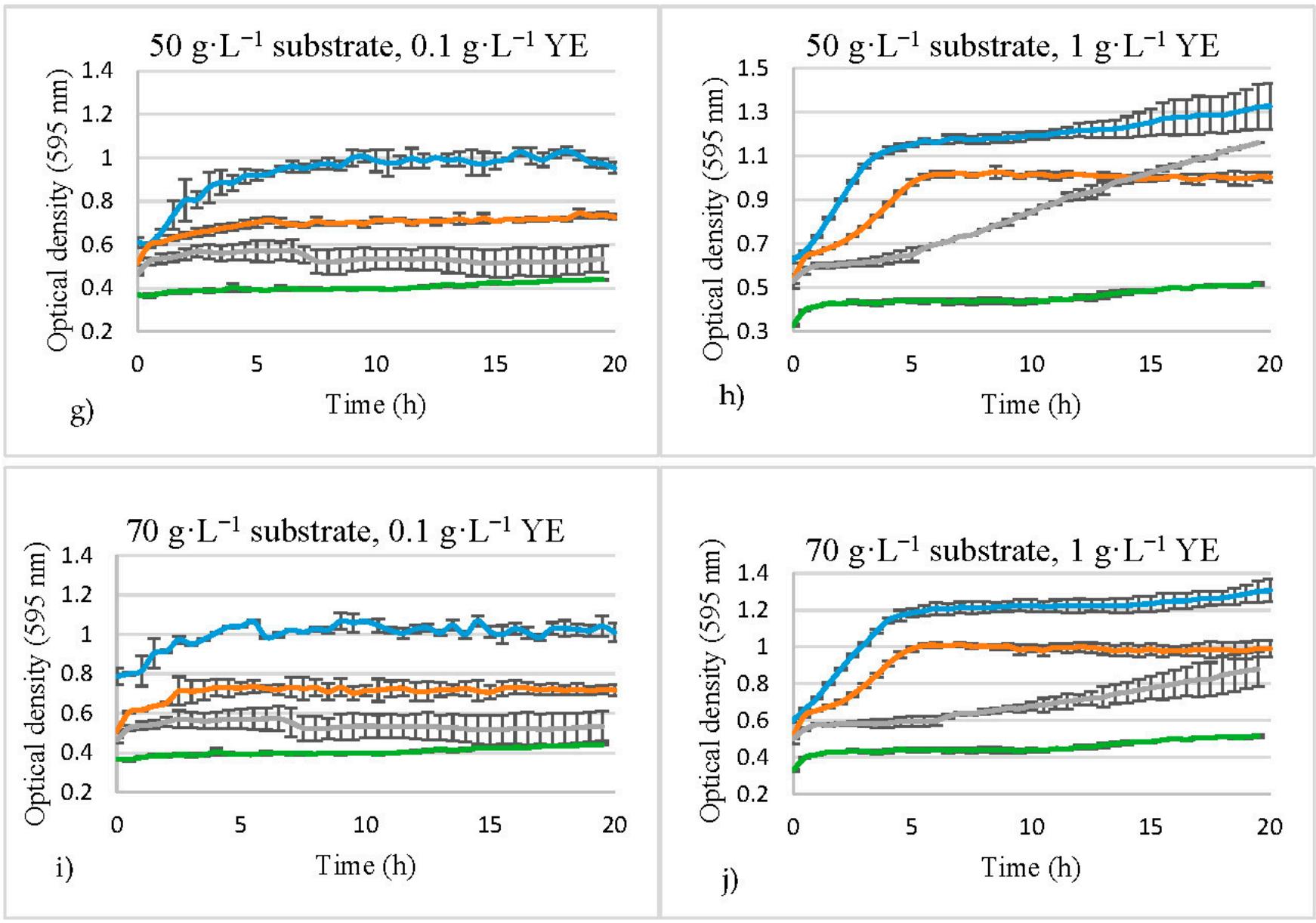

Figure 2. Effect of initial substrate and yeast extract (YE) concentration on B. succiniciproducens population growth dynamics in microplate experiments. Legend: orange line-glucose, blue line-xylose, grey line-glycerol, green line-control (without added bacteria). (a,c,e,g,i) shows the optical density over time with concentrations 5, 15, 30, 50, 70 g. $\mathrm{L}^{-1}$ respectively on glucose, glycerol and xylose with supplemented $0.1 \mathrm{~g} \cdot \mathrm{L}^{-1}$ YE. Subfigures $(\mathbf{b}, \mathbf{d}, \mathbf{f}, \mathbf{h}, \mathbf{j})$ presents the optical density over time with concentrations $5,15,30,50,70 \mathrm{~g} \cdot \mathrm{L}^{-1}$ respectively on glucose, glycerol and xylose with supplemented $1 \mathrm{~g} \cdot \mathrm{L}^{-1} \mathrm{YE}$.

In the following sets of experiments, we proposed to examine the population growth dynamics and metabolic profile of our strain, in a scaled-up and controlled environment, under the conditions identified in the previous step of our work. Briefly, the following parameters were used for bioreactor fermentations: $50 \mathrm{~g} \cdot \mathrm{L}^{-1}$ substrate (xylose, glucose, glycerol), $1 \mathrm{~g} \cdot \mathrm{L}^{-1}$ yeast extract in mineral medium.

Due to the fact that $B$. succiniciproducens is capnophilic bacterium, $\mathrm{CO}_{2}$ can be metabolized and may play a key role in the fermentation process [1]. To address this issue, fermentation experiments were performed in a bioreactor ( $1 \mathrm{~L}$ total volume) with a working volume of $0.5 \mathrm{~L}$, with $\mathrm{CO}_{2}$ sparging at a rate of $50 \mathrm{~cm}^{3} \cdot \mathrm{min}^{-1}$. Growth profiles of B. succiniciproducens in bioreactor cultures on three different substrates are presented in "Figure 3". 


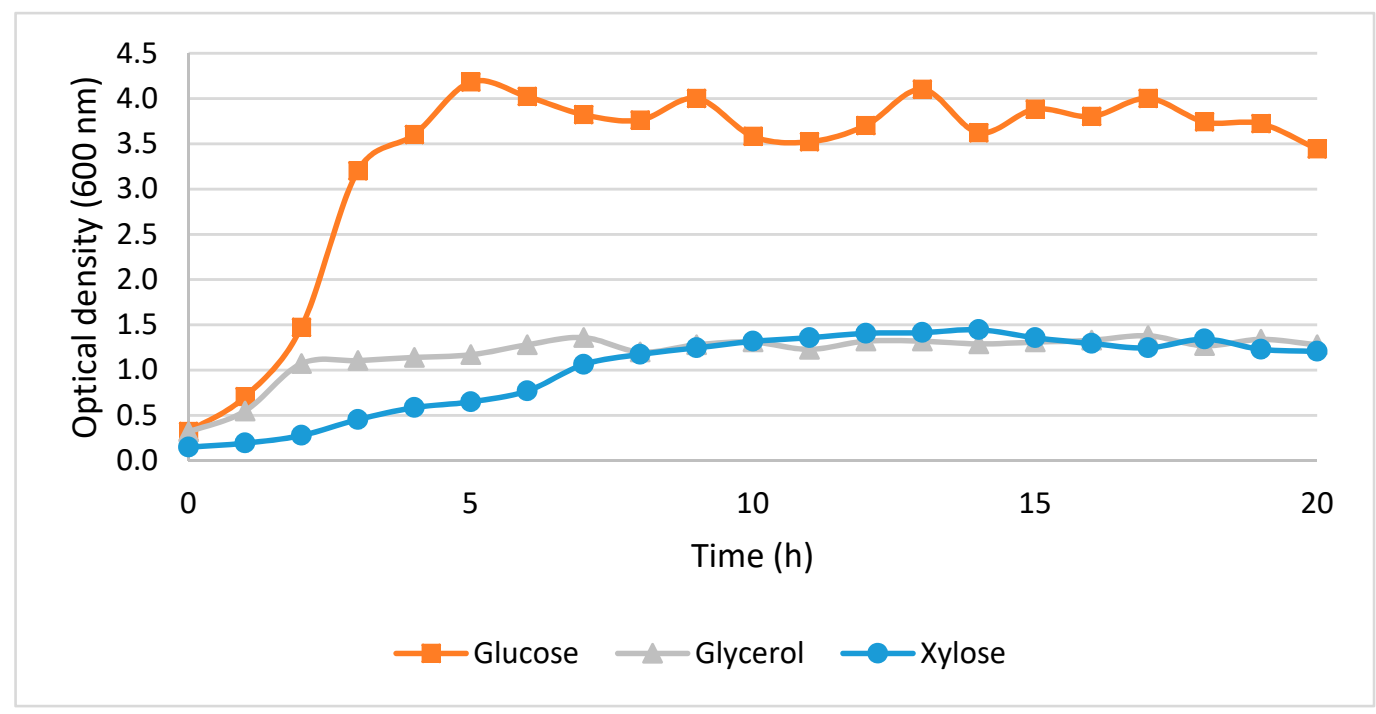

Figure 3. Population growth dynamics of B. succiniciproducens (strain DSMZ-22022) in bioreactor experiments, $\mathrm{CO}_{2}$ purging in headspace $\left(50 \mathrm{~cm}^{3} \cdot \mathrm{min}^{-1}\right)$ flowrate with substrates (glucose, xylose, glycerol) in $50 \mathrm{~g} \cdot \mathrm{L}^{-1}$ concentration.

Significant differences were observed in the bioreactor setting between glucose and the other substrates, mainly faster growth and short adaptation for glucose and the reached optical density being four times higher compared to xylose or glycerol. Glycerol and xylose consumption was slower, and the highest optical density during fermentation was only 1.2 for both substrates after $20 \mathrm{~h}$ of fermentation. Although the two substrates might present the same effect on the culture in terms of biomass production at the end of the fermentation period, there is a significant difference in the adaptation period for the two cultures: the culture grown on xylose needed a three-times longer adaptation period compared to the glycerol-fed cultures until reaching the plateau phase of growth. A higher reduction grade in the case of glycerol, which can cause significant redox imbalance in the cell, can result in reduced growth rate in the case of this substrate, which could explain the lower biomass production through fermentation [47]. In the case of xylose, however, we observed a different behavior of our strain in the bioreactor setting compared to our small-volume experiments, the growth profile in the bioreactor culture being closer to the less assimilated glycerol-fed culture. One possible explanation could be the $\mathrm{CO}_{2}$ atmosphere with reduced $\mathrm{O}_{2}$ inlet, which could limit biomass formation by inhibition of $\mathrm{NAD}^{+}$regeneration via the oxygen-dependent NADH oxidase step [48].

As previously reported, the wild type of the studied microorganism can naturally produce relatively high amounts of succinic acid from different carbon sources. To assess the metabolic potential of our cultures grown on different carbon sources in mineral medium, the produced metabolites (succinic acid, acetic acid, formic acid and lactic acid) were analyzed at the end of the fermentation ("Figure 4"). 


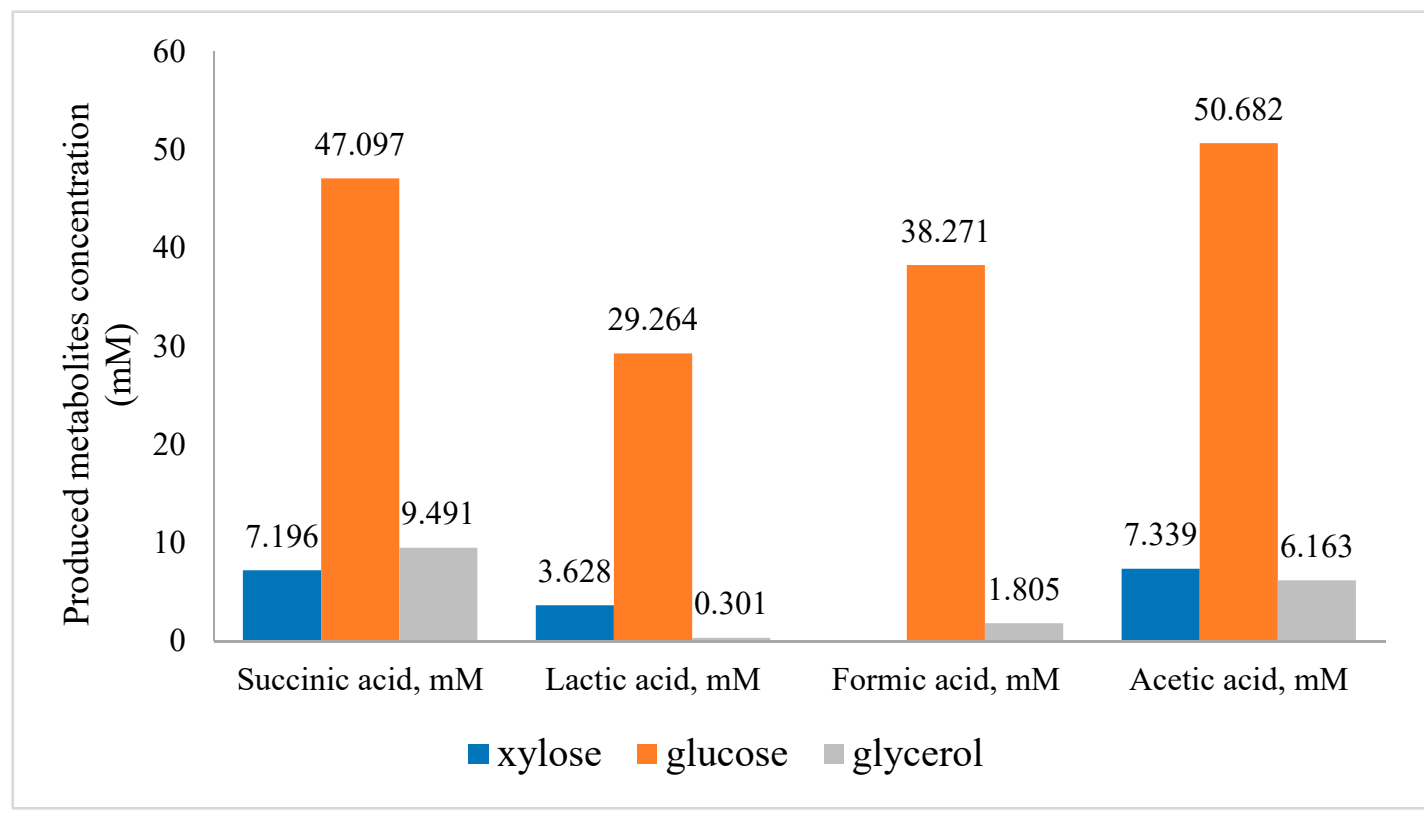

Figure 4. Batch fermentation profiles of B. succiniciproducens for organic acid production (succinic acid, lactic acid, formic acid, acetic acid) obtained in bioreactor for xylose, glucose and glycerol after $20 \mathrm{~h}$ of fermentation.

Based on the obtained data, we can conclude that the highest amount of succinic acid, $47.097 \mathrm{mM}$, was reached after $20 \mathrm{~h}$ of fermentation in the case of glucose, and acetic, formic and lactic acid were the major organic acid by-products. In the case of glycerol, around $79 \%$ lower succinic acid production was observed at the same time point, with a $9.491 \mathrm{mM}$ concentration. In the case of xylose, the highest measured succinic acid concentration was $7.196 \mathrm{mM}$. In order to increase the production of succinic acid, it is necessary to optimize the fermentation conditions and to reduce or eliminate the by-product formation, e.g., by a metabolic engineering approach and long-term adaptation experiments.

\section{Conclusions}

Mathematical models describing metabolic systems are powerful tools to analyze the metabolic potential of different organisms under different environmental conditions and to decipher the possible modification necessary to design industrially important strains. The in silico simulation results revealed the metabolic reconstruction of B. succiniciproducens, even if it is not a genome-scale reconstruction, can be used to analyze the most important metabolic functions and make predictions regarding the growth and production rate of organic acids, including succinic acid as well. Bacterial behavior, in the case of the natural succinic acid producer B. succiniciproducens as a result of different environmental effects, was investigated based on fermentation data. The present study provides valuable information about the strain growth potential on different renewable carbon sources (glucose, xylose and glycerol), as well as the effect of additives on population growth dynamics. Our goal was to show the effect of yeast extract concentration on cellular growth, while the obtained data shows a clear difference between the two studied yeast extract concentrations.

According to the literature, B. succiniciproducens is a robust succinic acid producer with a wide substrate utilization spectrum, while in-depth physiological description of the species is scarce. Our results revealed the effect of substrate concentration on the population growth dynamics of the strain. Our data suggest that the strain can produce biomass over a wide range of substrate concentrations, for example, it can reach $\mathrm{OD}_{595}$ 1.3 value on xylose (70 g. $\mathrm{L}^{-1}$ substrate concentration). According to our findings, in the case of glycerol, we determined a substrate inhibition concentration of $50 \mathrm{~g} \cdot \mathrm{L}^{-1}$ that affects growth and biomass formation of the strain. The addition of $1 \mathrm{~g} \cdot \mathrm{L}^{-1}$ yeast extract, 
compared to $0.1 \mathrm{~g} \cdot \mathrm{L}^{-1}$ yeast extract, had a higher positive impact over bacterial growth in all examined conditions.

According to our studies conducted in the bioreactor set up under $\mathrm{CO}_{2}$ atmosphere, glucose was the most suitable substrate. The metabolite profile of fermentation showed the presence of metabolic by-products (acetic acid, formic acid and lactic acid) and the target product, succinic acid, was formed. Our findings suggest that lignocellulosic feedstocks (containing glucose, xylose) can be utilized as industrial substrates, and would be a cost efficient solution for the production of high added-value components, such as succinic acid [49]. The highest succinic acid concentration, $5.55 \mathrm{~g} \cdot \mathrm{L}^{-1}(47.097 \mathrm{mM})$, reached is comparable to those presented in the literature: $4.6-6.4 \mathrm{~g} \cdot \mathrm{L}^{-1}$ with glycerol [35], $26 \mathrm{~g} \cdot \mathrm{L}^{-1}$ using xylose [36], and $30 \mathrm{~g} \cdot \mathrm{L}^{-1}$ on lignocellulosic hydrolysate, used as main carbon sources [50].

Author Contributions: Conceptualization, I.M.; Data curation, I.H.K.; Formal analysis, H.B.; Investigation, H.B., M.B. and I.H.K.; Methodology, M.B.; Project administration, S.L. and I.M.; Supervision, S.L.; Validation, S.L.; Visualization, H.B.; Writing—original draft, H.B.; Writing—review and editing, I.M. All authors have read and agreed to the published version of the manuscript.

Funding: This project was supported by the Sapientia University 2017/2018 Research Program, grant nr. 227/2/17.05.2017.

Data Availability Statement: Chemicals for lab experiments were purchased from VWR (vwr. com) and Sigma-Aldrich (sigmaaldrich.com). Accessing date: 8 November 2019 and 8 December 2019 respectively.

Acknowledgments: The authors thanks the support from Doctoral School of Chemistry, University of Pécs.

Conflicts of Interest: The authors declare no conflict of interest.

Ethics Approval and Consent to Participate: The manuscript it is not submitted to more than one journal for consideration. This work is original and it is not published elsewhere in any form or language. In the manuscript experiments no human subject was included for whom the participate consent should be declared.

\section{References}

1. Kuhnert, P.; Scholten, E.; Haefner, S.; Mayor, D.; Frey, J. Basfia succiniciproducens gen. nov., sp. nov., a new member of the family Pasteurellaceae isolated from bovine rumen. Int. J. Syst. Evol. Microbiol. 2010, 60, 44-50. [CrossRef]

2. Becker, J.; Lange, A.; Fabarius, J.; Wittmann, C. Top value platform chemicals: Bio-based production of organic acids. Curr. Opin. Biotechnol. 2015, 36, 168-175. [CrossRef] [PubMed]

3. Cimini, D.; Argenzio, O.; D'Ambrosio, S.; Lama, L.; Finore, I.; Finamore, R.; Pepe, O.; Faraco, V.; Schiraldi, C. Production of succinic acid from Basfia succiniciproducens up to the pilot scale from Arundo donax hydrolysate. Bioresour. Technol. 2016, 222, 355-360. [CrossRef] [PubMed]

4. Nghiem, N.P.; Kleff, S.; Schwegmann, S. Succinic Acid: Technology Development and Commercialization. Fermentation 2017, 3, 26. [CrossRef]

5. Szép, R.; Bodor, Z.; Miklóssy, I.; Niță, I.-A.; Oprea, O.A.; Keresztesi, Á. Influence of peat fires on the rainwater chemistry in intra-mountain basins with specific atmospheric circulations (Eastern Carpathians, Romania). Sci. Total Environ. 2019, 647, 275-289. [CrossRef]

6. Szép, R.; Mateescu, E.; Niță, I.-A.; Birsan, M.-V.; Bodor, Z.; Keresztesi, Á. Effects of the Eastern Carpathians on atmospheric circulations and precipitation chemistry from 2006 to 2016 at four monitoring stations (Eastern Carpathians, Romania). Atmos. Res. 2018, 214, 311-328. [CrossRef]

7. Szép, R.; Mateescu, E.; Nechifor, A.C.; Keresztesi, Á. Chemical characteristics and source analysis on ionic composition of rainwater collected in the Carpathians 'Cold Pole,' Ciuc basin, Eastern Carpathians, Romania. Environ. Sci. Pollut. Res. Int. 2017, 24, 27288-27302. [CrossRef] [PubMed]

8. Keresztesi, A.; Sandor, P.; Ghita, G.; Dumitru, F.D.; Moncea, M.A.; Ozunu, A.; Szep, R. Ammonium Neutralization Effect on Rainwater Chemistry in the Basins of the Eastern Carpathians-Romania. Rev. Chim. 2018, 69, 57-63. [CrossRef]

9. Korodi, A.; Petres, S.; Keresztesi, Á. Sustainable Development. Theory or Practice? In Proceedings of the International Multidisciplinary Scientific GeoConference \& EXPO SGEM2017, Albena, Bulgaria, 29 June-5 July 2017; p. 8.

10. Keresztesi, Á.; Birsan, M.-V.; Nita, I.-A.; Bodor, Z.; Robert, S. Assessing the neutralisation, wet deposition and source contributions of the precipitation chemistry over Europe during 2000-2017. Environ. Sci. Eur. 2019, 31. [CrossRef] 
11. Keresztesi, Á.; Nita, I.-A.; Birsan, M.-V.; Bodor, Z.; Pernyeszi, T.; Micheu, M.M.; Szép, R. Assessing the variations in the chemical composition of rainwater and air masses using the zonal and meridional index. Atmos. Res. 2020, 237, 104846. [CrossRef]

12. Keresztesi, Á.; Nita, I.-A.; Birsan, M.-V.; Bodor, Z.; Szép, R. The risk of cross-border pollution and the influence of regional climate on the rainwater chemistry in the Southern Carpathians, Romania. Environ. Sci. Pollut. Res. 2020, 27, 9382-9402. [CrossRef] [PubMed]

13. Szep, R.; Keresztes, R.; Deak, G.; Toba, F.; Ghimpusan, M. The Dry Deposition of the PM10 and PM2. 5 to the Vegetation and its Health Effect in the Ciuc Basin. Rev. Chim. 2016, 67, 639-644.

14. Szep, R.; Matyas, L. The role of regional atmospheric stability in high-PM10 concentration episodes in Miercurea Ciuc (Harghita). Carpathian J. Earth Environ. Sci. 2014, 9, 241-250.

15. Petres, S.; Szabolcs, L.; Piriianu, M.; Keresztesi, Á.; Nechifor, A. Evolution of Tropospheric Ozone and Relationship with Temperature and NOx for the 2007-2016 Decade in the Ciuc Depression. Rev. Chim. 2018, 69. [CrossRef]

16. Ferone, M.; Ercole, A.; Raganati, F.; Olivieri, G.; Salatino, P.; Marzocchella, A. Efficient succinic acid production from high-sugarscontent beverages (HSCBs) by Actinobacillus succinogenes. Biotechnol. Prog. 2019, 35. [CrossRef] [PubMed]

17. Louasté, B.; Eloutassi, N. Succinic acid production from whey and lactose by Actinobacillus succinogenes $130 \mathrm{Z}$ in batch fermentation. Biotechnol. Rep. 2020, 27, e00481. [CrossRef]

18. Zhang, A.Y.-Z.; Sun, Z.; Leung, C.C.J.; Han, W.; Lau, K.Y.; Li, M.; Lin, C.S.K. Valorisation of bakery waste for succinic acid production. Green Chem. 2013, 15, 690-695. [CrossRef]

19. Ramesh, H.P.; Tharanathan, R.N. Carbohydrates-The Renewable Raw Materials of High Biotechnological Value. Crit. Rev. Biotechnol. 2003, 23, 149-173. [CrossRef]

20. Kuenz, A.; Jäger, M.; Niemi, H.; Kallioinen, M.; Mänttäri, M.; Prüße, U. Conversion of Xylose from Birch Hemicellulose Hydrolysate to 2,3-Butanediol with Bacillus vallismortis. Fermentation 2020, 6, 86. [CrossRef]

21. Harabi, M.; Bouguerra, S.N.; Marrakchi, F.; Chrysikou, L.P.; Bezergianni, S.; Bouaziz, M. Biodiesel and Crude Glycerol from Waste Frying Oil: Production, Characterization and Evaluation of Biodiesel Oxidative Stability with Diesel Blends. Sustainability 2019, 11, 1937. [CrossRef]

22. Cimini, D.; Zaccariello, L.; D’Ambrosio, S.; Lama, L.; Ruoppolo, G.; Pepe, O.; Faraco, V.; Schiraldi, C. Improved production of succinic acid from Basfia succiniciproducens growing on A. donax and process evaluation through material flow analysis. Biotechnol. Biofuels 2019, 12, 22. [CrossRef]

23. Lee, J.W.; Yi, J.; Kim, T.Y.; Choi, S.; Ahn, J.H.; Song, H.; Lee, M.-H.; Lee, S.Y. Homo-succinic acid production by metabolically engineered Mannheimia succiniciproducens. Metab. Eng. 2016, 38, 409-417. [CrossRef] [PubMed]

24. Saha, B.C.; Kennedy, G.J. Efficient itaconic acid production by Aspergillus terreus: Overcoming the strong inhibitory effect of manganese. Biotechnol. Prog. 2020, 36. [CrossRef] [PubMed]

25. Miklóssy, I.; Bodor, Z.; Sinkler, R.; Orbán, K.C.; Lányi, S.; Albert, B. In silico and in vivo stability analysis of a heterologous biosynthetic pathway for 1,4-butanediol production in metabolically engineered E. coli. J. Biomol. Struct. Dyn. 2017, 35, 1874-1889. [CrossRef] [PubMed]

26. Bodor, Z.; Kovács, E.; Albert, B. Systems biology and metabolic engineering for obtaining E. coli mutants capable to produce succinate from renewable resources. Rom. Biotechnol. Lett. 2014, 19, 12.

27. Bodor, Z.; Tompos, L.; Nechifor, A.C.; Bodor, K. In silico Analysis of 1,4-butanediol Heterologous Pathway Impact on Escherichia coli Metabolism. Rev. Chim. 2019, 70, 3448-3455. [CrossRef]

28. Bodor, Z.; Lanyi, S.; Albert, B.; Bodor, K.; Nechifor, A.C.; Miklossy, I. Model Driven Analysis of the Biosynthesis of 1,4-butanediol from Renewable Feedstocks in Escherichia coli. Rev. Chim. 2019, 70, 3808-3817. [CrossRef]

29. Bodor, Z.; Fazakas, A.; Kovács, E.; Szabolcs, L.; Ábrahám, B. Biotechnological production of succinic acid from glycerol; The role of co-substrates. Stud. Univ. Babes, Bolyai Chem. 2014, 59, 33-50.

30. Fazakas, A.; Csató-Kovács, E.; Bodor, Z.; Lányi, S.; Ábrahám, B. Production of Chemicals with Genetically Modified Escherichia coli Strains from Renewable Resources. Stud. Univ. Babeș Bolyai Chem. 2016, 61, 35-46.

31. Lange, A.; Becker, J.; Schulze, D.; Cahoreau, E.; Portais, J.-C.; Haefner, S.; Schröder, H.; Krawczyk, J.; Zelder, O.; Wittmann, C. Bio-based succinate from sucrose: High-resolution $13 \mathrm{C}$ metabolic flux analysis and metabolic engineering of the rumen bacterium Basfia succiniciproducens. Metab. Eng. 2017, 44, 198-212. [CrossRef]

32. der Werf, M.J.V.; Guettler, M.V.; Jain, M.K.; Zeikus, J.G. Environmental and physiological factors affecting the succinate product ratio during carbohydrate fermentation by Actinobacillus sp. 130 Z. Arch. Microbiol. 1997, 167, 332-342. [CrossRef] [PubMed]

33. Zheng, P.; Fang, L.; Xu, Y.; Dong, J.-J.; Ni, Y.; Sun, Z.-H. Succinic acid production from corn stover by simultaneous saccharification and fermentation using Actinobacillus succinogenes. Bioresour. Technol. 2010, 101, 7889-7894. [CrossRef] [PubMed]

34. Xu, H.; Zhou, Z.; Wang, C.; Chen, Z.; Cai, H. Enhanced succinic acid production in Corynebacterium glutamicum with increasing the available NADH supply and glucose consumption rate by decreasing H+-ATPase activity. Biotechnol. Lett. 2016, 38, 1181-1186. [CrossRef]

35. Scholten, E.; Renz, T.; Thomas, J. Continuous cultivation approach for fermentative succinic acid production from crude glycerol by Basfia succiniciproducens DD1. Biotechnol. Lett. 2009, 31, 1947-1951. [CrossRef] [PubMed]

36. Pateraki, C.; Almqvist, H.; Ladakis, D.; Lidén, G.; Koutinas, A.A.; Vlysidis, A. Modelling succinic acid fermentation using a xylose based substrate. Biochem. Eng. J. 2016, 114, 26-41. [CrossRef] 
37. Chen, K.-Q.; Li, J.; Ma, J.-F.; Jiang, M.; Wei, P.; Liu, Z.-M.; Ying, H.-J. Succinic acid production by Actinobacillus succinogenes using hydrolysates of spent yeast cells and corn fiber. Bioresour. Technol. 2011, 102, 1704-1708. [CrossRef] [PubMed]

38. Liu, R.; Liang, L.; Li, F.; Wu, M.; Chen, K.; Ma, J.; Jiang, M.; Wei, P.; Ouyang, P. Efficient succinic acid production from lignocellulosic biomass by simultaneous utilization of glucose and xylose in engineered Escherichia coli. Bioresour. Technol. 2013, 149, 84-91. [CrossRef]

39. Jiang, M.; Ma, J.; Wu, M.; Liu, R.; Weiliang, D.; Xin, F.; Zhang, W.; Jia, H.; Dong, W. Progress of succinic acid production from renewable resources: Metabolic and fermentative strategies. Bioresour. Technol. 2017, 245, 1710-1717. [CrossRef] [PubMed]

40. Scholten, E.; Dägele, D. Succinic acid production by a newly isolated bacterium. Biotechnol. Lett. 2008, 30, 2143-2146. [CrossRef]

41. Ventorino, V.; Robertiello, A.; Cimini, D.; Argenzio, O.; Schiraldi, C.; Montella, S.; Faraco, V.; Ambrosanio, A.; Viscardi, S.; Pepe, O. Bio-Based Succinate Production from Arundo donax Hydrolysate with the New Natural Succinic Acid-Producing Strain Basfia succiniciproducens BPP7. BioEnergy Res. 2017, 10, 488-498. [CrossRef]

42. Wallenius, J.; Maaheimo, H.; Eerikäinen, T. Carbon 13-Metabolic Flux Analysis derived constraint-based metabolic modelling of Clostridium acetobutylicum in stressed chemostat conditions. Bioresour. Technol. 2016, 219, 378-386. [CrossRef] [PubMed]

43. Orth, J.D.; Thiele, I.; Palsson, B.Ø. What is flux balance analysis? Nat. Biotechnol. 2010, 28, 3. [CrossRef] [PubMed]

44. Becker, J.; Reinefeld, J.; Stellmacher, R.; Schäfer, R.; Lange, A.; Meyer, H.; Lalk, M.; Zelder, O.; Von Abendroth, G.; Schröder, H.; et al. Systems-wide analysis and engineering of metabolic pathway fluxes in bio-succinate producing Basfia succiniciproducens: Systems-Wide Analysis and Engineering. Biotechnol. Bioeng. 2013, 110, 3013-3023. [CrossRef] [PubMed]

45. Becker, S.A.; Feist, A.M.; Mo, M.L.; Hannum, G.; Palsson, B.Ø.; Herrgard, M.J. Quantitative prediction of cellular metabolism with constraint-based models: The COBRA Toolbox. Nat. Protoc. 2007, 2, 3. [CrossRef] [PubMed]

46. Schellenberger, J.; Que, R.; Fleming, R.M.T.; Thiele, I.; Orth, J.D.; Feist, A.M.; Zielinski, D.C.; Bordbar, A.; Lewis, N.E.; Rahmanian, S.; et al. Quantitative prediction of cellular metabolism with constraint-based models: The COBRA Toolbox v2.0. Nat. Protoc. 2011, 6, 9. [CrossRef]

47. Murarka, A.; Dharmadi, Y.; Yazdani, S.S.; Gonzalez, R. Fermentative Utilization of Glycerol by Escherichia coli and Its Implications for the Production of Fuels and Chemicals. Appl. Environ. Microbiol. 2008, 74, 1124-1135. [CrossRef]

48. Sun, F.; Dai, C.; Xie, J.; Hu, X. Biochemical Issues in Estimation of Cytosolic Free NAD/NADH Ratio. PLoS ONE 2012, 7, e34525. [CrossRef]

49. Kim, S. Xylitol Production From Byproducts Generated During Sequential Acid-/Alkali-Pretreatment of Empty Palm Fruit Bunch Fiber by an Adapted Candida tropicalis. Front. Energy Res. 2019, 7, 72. [CrossRef]

50. Salvachúa, D.; Smith, H.; John, P.C.S.; Mohagheghi, A.; Peterson, D.J.; Black, B.A.; Dowe, N.; Beckham, G.T. Succinic acid production from lignocellulosic hydrolysate by Basfia succiniciproducens. Bioresour. Technol. 2016, 214, 558-566. [CrossRef] 